\title{
Analisis Pertumbuhan Ekonomi Daerah Provinsi Jambi
}

\author{
Nurdin \\ Ekonomi Pembangunan, STIE Muhammadiyah Jambi \\ e-mail : oedinnurdin@gmail.com
}

\begin{abstract}
This study uses secondary data collected by the object of research in Jambi Province in the form of factors affecting the economic growth of Jambi Province sourced from the Central Bureau of Statistics (BPS). Data were collected during the period 2004 to 2015. The purpose of this study is to analyze and know what factors affect the economic growth of Jambi Province period 2004-2015. The analytical tool used is this research using econometric analysis tool with Ordinary Least Square (OLS) method with multiple linear regression equation through the aid of SPSS software program. 21:00. Based on the discussion of data analysis results in this study, it can be concluded the result of $R$-squared calculation shown in the above equation obtained $R^{2}$ value of 0.989. This shows that about 98.90 percent of the upturned economic growth (Yt) in Jambi Province is influenced by investment variable $\left(X_{1} t\right)$, capital expenditure $\left(X_{2} t\right)$, working population $\left(X_{3} t\right)$, unemployment $\left(X_{4} t\right)$ and poverty $\left(X_{5} t\right)$. While the remaining 1.10 percent, explained by other variables that are not included into the regression equation.
\end{abstract}

Keywords: Economic Growth, Investment, Capital Expenditure, Working Population, Unemployment And Poverty

\section{PENDAHULUAN}

Keberhasilan pembangunan suatu daerah dapat dilihat dari tingkat pertumbuhan ekonominya. Oleh sebab itu, setiap daerah selalu menetapkan target tingkat pertumbuhan ekonomi yang tinggi didalam perencanaan dan tujuan pembangunan daerahnya. Pertumbuhan ekonomi yang tinggi dan berkelanjutan merupakan kondisi utama bagi kelangsungan pembangunan ekonomi. Pertumbuhan ekonomi diartikan sebagai proses kenaikan output perkapita dalam jangka panjang (Boediono, 2008). Kata "perkapita" menunjukkan ada dua sisi yang perlu diperhatikan, yaitu sisi output totalnya (PDRB) dan sisi jumlah penduduk. Proses kenaikan output perkapita, tidak bisa tidak, harus dianalisa dengan jalan melihat apa yang terjadi dengan output total disatu pihak, dan jumlah penduduk dipihak lain. Sehingga menjelaskan apa yang terjadi dengan PDRB total dan apa yang terjadi pada jumlah penduduk. Oleh karena itu, posisi penduduk dalam pembangunan ekonomi menjadi penting karena pertumbuhan ekonomi sendiri selalu terkait dengan jumlah penduduk.

Fluktuasi jumlah penduduk bekerja tersebut disebabkan oleh banyak faktor, misalnya dipengaruhi oleh keadaan-keadaan ekonomi, politik dan juga sosial yang berkembang di masyarakat. Pada umumnya daerah-daerah di Indonesia termasuk Provinsi Jambi kerap mengalami tekanan penduduk yang semakin meningkat tiap tahunnya. Peningkatan jumlah serta pertumbuhan penduduk yang semakin meningkat tersebut dibarengi dengan belum seimbangnya kegiatan ekonomi khususnya kesempatan kerja yang tersedia sehingga menciptakan 
permasalahan sosial ekonomi yang serius, rendahnya tingkat kesehatan dan pendidikan serta semakin tingginya angka kriminalitas yang berdampak pada aspek keamanan yang pada gilirannya akan menghambat kegiatan perekonomian itu sendiri baik itu belanja modal, investasi dan tenaga kerja. Peningkatan jumlah penduduk miskin memberikan gambaran bahwa laju pertumbuhan ekonomi yang cenderung positif diikuti pula dengan kecenderungan penurunan jumlah penduduk miskin. Jelaslah bahwa semakin cepat laju pertumbuhan ekonomi diharapkan akan semakin besar pula dampaknya terhadap penurunan angka kemiskinan pada masyarakat, namun demikian pada kenyataannya laju pertumbuhan ekonomi yang tinggi belum tentu menjamin peningkatan kesejahteraan masyarakat. Pertumbuhan ekonomi lebih banyak ditopang oleh pemilik modal yang memiliki dana untuk membangun perusahaan dan membeli lahan serta bahan-bahan baku untuk kegiatan usahanya. Dalam kondisi demikian diperlukan kebijakan yang tepat agar distribusi pendapatan dapat lebih merata dan menjangkau masyarakat kecil, khususnya masyarakat yang tidak mampu.

Untuk mengurangi tingkat kemiskinan di Provinsi Jambi dapat dilaksanakan melalui pertumbuhan ekonomi yang berkualitas. Maka dari itu perlu diketahui sebenarnya faktor-faktor apa sajakah yang berhubungan atau mempengaruhi tinggi rendahnya pertumbuhan ekonomi sehingga kedepannya dapat diformulasikan sebuah kebijakan publik yang efektif untuk mengurangi tingkat kemiskinan dan tidak hanya sekedar penurunan angka-angka saja melainkan secara kualitatif. Tujuan dari penelitian ini adalah menganalisis dan mengetahui faktor-faktor apa saja yang mempengaruhi pertumbuhan ekonomi Provinsi Jambi periode tahun 2004-2015.

\section{Tinjauan Pustaka}

\section{Konsep Pertumbuhan Ekonomi}

Boediono (2008), mengatakan bahwa pertumbuhan ekonomi adalah proses kenaikan output perkapita dalam jangka panjang. Defenisi ini menekankan pada aspek: (1) perekonomian berkembang dari waktu ke waktu; (2) kenaikan output perkapita, karena kenaikan pendapatan akan mengakibatkan peningkatan kesejahteraan perekonomian masyarakat, dan agar pendapatan perkapita naik maka pertumbuhan ekonomi harus lebih tinggi dari pada pertumbuhan penduduk; dan (3) aspek lainnya adalah pertumbuhan ekonomi harus berlangsung dalam jangka panjang dimana jangka waktu yang cukup panjang output per kapita mempunyai kecenderungan yang meningkat dapat dikatakan terjadi pertumbuhan ekonomi walau bisa saja terjadi suatu tahun tertentu output perkapita menurun.

Wijaya (2009) menyatakan bahwa pertumbuhan ekonomi merupakan keadaan dimana terjadi kenaikan Produk Nasional Bruto atau Pendapatan Nasional Rill. Pertumbuhan ekonomi terjadi apabila ada kenaikan output per kapita. Menurut Arsyad (2009) pertumbuhan diartikan sebagai kenaikan GDP/GNP tanpa memandang apakah kenaikan itu lebih besar atau lebih kecil dari tingkat pertumbuhan penduduk, atau apakah ada perubahan struktur ekonomi atau tidak.

Kuznets dalam Arsyad (2009) mendefenisi pertumbuhan ekonomi suatu negara sebagai peningkatan 
kemampuan suatu negara untuk menyediakan berbagai barang ekonomi bagi penduduknya, pertumbuhan kemampuan ini disebabkan oleh kemajuan teknologi dan kelembagaan serta penyesuaian ideology yang dibutuhkannya. Ketiga komponen pokok dari defenisi ini sangat penting artinya: (1) kenaikan output nasional secara terus menerus merupakan perwujudan dari pertumbuhan ekonomi dan kemampuan untuk menyediakan berbagai macam barang ekonomi merupakan tanda kematangan ekonomi; (2) kemajuan teknologi merupakan prasyarat bagi pertumbuhan ekonomi yang berkesinambungan, namun belum merupakan syarat yang cukup. Untuk merealisasikan potensi pertumbuhan yang terkandung dalam teknologi baru maka diperlukan kemampuan sumberdaya manusia yang memadai; dan (3) penyesuaian kelembagaan, sikap dan ideology harus dilakukan. Inovasi teknologi tanpa disertai inovasi sosial ibarat bola lampu tanpa aliran listrik. Potensi ada tetapi tanpa input yang melengkapi tidak akan berarti apa-apa.

Todaro (2003) mengatakan ada 3 (tiga) faktor atau komponen utama dalam pertumbuhan ekonomi yaitu : (1) akumulasi modal, terjadi apabila sebagian dari pendapatan ditabung dan diinvestasikan untuk menambah produksi dan pendapatan dikemudian hari. Ini juga merupakan suatu investasi yang produktif dan langsung dilengkapi dengan investasi penunjang, yaitu bisa juga bersifat tidak langsung untuk menginvestasikan pada sumberdaya manusia mempunyai pengaruh yang sama atau mungkin lebih baik terhadap peningkatan produksi; (2) pertumbuhan penduduk dan angkatan kerja secara tradisional dikatakan sebagai salah satu faktor yang memacu pertumbuhan ekonomi. Angkatan kerja yang lebih besar berarti tenaga kerja produktif yang lebih besar dan jumlah penduduk yang lebih besar berarti memperluas potensi pasar domestik; dan (3) kemajuan teknologi, dimana hal ini bagi kebanyakan ekonomi dan utamanya teknokrat merupakan sumber pertumbuhan ekonomi yang paling penting. Karena perbaikan atas cara-cara lama dalam menangani pekerjaan-pekerjaan tradisional, dan dalam hal ini dikenal tiga klasifikasi teknologi yaitu bersifat netral, hemat tenaga kerja dan hemat modal.

\section{Konsep Belanja Modal}

Belanja Modal merupakan salah satu jenis Belanja Langsung dalam APBN/APBD. Menurut Erlina dan Rasdianto (2013) Belanja Modal adalah pengeluaran anggaran untuk aset tetap berwujud yang memberi manfaat lebih dari satu periode akuntansi. Besaran nilai pembelian/pengadaan atau pembangunan aset tetap berwujud dianggarkan dalam belanja modal hanya sebesar harga beli/bangun aset (Permendagri 13 Tahun 2006). Lampiran III PMK No. 101/PMK.02/2011 Belanja Modal dipergunakan untuk antara lain: Belanja Modal Tanah, Belanja Modal Peralatan dan Mesin, Belanja Modal Gedung dan bangunan, Belanja Modal Jalan Irigasi dan Jaringan, Belanja Modal lainnya, dan Belanja Modal Badan Layanan Umum (BLU). Secara spesifik sumber pendanaan untuk Belanja Modal belum ditentukan aturannya. Namun seluruh jenis sumber-sumber penerimaan daerah dapat dialokasikan untuk mendanai Belanja Daerah diantaranya Belanja Modal. Sumber-sumber penerimaan daerah (UU Nomor 33 Tahun 2004) yang 
dapat digunakan sebagai sumber pendaaan Belanja Daerah berasal dari Pendapatan Daerah dan Pembiayaan. Pendapatan Daerah bersumber dari: (1) Pendapatan Asli Daerah (PAD) yaitu: Pajak Daerah, Retribusi Daerah, Hasil pengelolaan kekayaan daerah yang dipisahkan, dan Lain-lain PAD yang sah; (2) Dana Perimbangan yaitu: Dana Bagi Hasil, Dana Alokasi Umum, dan Dana Alokasi Khusus; dan (3) Lain-Lain pendapatan yang sah yaitu: Hasil Penjualan kekayaan Daerah yang tidak dipisahkan, Jasa Giro, Pendapatan bunga, Keuntungan selisih nilai tukar rupiah terhadap mata uang asing, dan Komisi, potongan, ataupun bentuk lain sebagai akibat dari penjualan dan/atau pengadaan barang dan/atau jasa oleh Daerah.

Dari teori diatas peneliti mencoba menguraikan beberapa faktor yang mempengaruhi besarnya alokasi Belanja Modal Pemda dalam APBD yaitu:

1. Kelemahan perencanaan belanja pemerintah daerah.

Proporsi alokasi belanja daerah masih didominasi kepentingan operasional rutin pemerintahan seperti belanja barang dan belanja pegawai dibandingkan dengan alokasi belanja untuk kegiatan yang langsung bersentuhan dengan kebutuhan publik. Hal ini tentunya mempengaruhi besarnya anggaran Belanja Modal Pemda.

2. Ketersediaan sumbersumber dana belanja daerah. Pendapatan Daerah dan Pembiayaan merupakan sumber-sumber dana belanja daerah. Apabila PAD terbatas untuk membiayai belanja daerah maka diperlukan adanya bantuan dana transfer (DAU, DBH, DAK) dari pemerintah pusat untuk membantu pendanaan belanja daerah dan menggunakan dana Pembiayaan (SiLPA, Pinjaman) bila terjadi defisit anggaran. Apabila tidak tersedia sumber-sumber dana belanja daerah yang cukup maka sangat riskan untuk bisa menyediakan anggaran yang besar khususnya untuk Belanja Modal.

3. Luasnya daerah yang perlu dikembangkan dan dibangun. Daerah yang padat pembangunan tentunya tidak membutuhkan alokasi Belanja Modal yang banyak. Pengalokasian dana pemeliharaanlah yang perlu ditingkatkan. Namun bagi daerah yang baru dimekarkan tentunya membutuhkan alokasi dana yang sangat besar pada Belanja Modalnya. Daerah pemekaran membutuhkan banyak pembenahan, pembangunan dan penyediaan sarana dan prasarana publik yang memadai dalam usaha peningkatan kesejahteraan masyarakat sehingga daerah tersebut memiliki daya saing yang kuat dengan daerah lainnya.

Straub (2008) menjelaskan bahwa teori pertumbuhan modern menekankan kemungkinan peran belanja modal dalam mendorong pertumbuhan ekonomi. Dalam penelitiannya efek langsung 
peningkatan Belanja modal adalah dapat secara langsung mempengaruhi produktivitas faktorfaktor lain yang dapat merangsang peningkatan output ekonomi. Dan secara tidak langsung terkait dengan eksternalitas. Dengan adanya infrastruktur yang berkualitas maka dapat mengurangi biaya ketergantungan terhadap sektor swasta seperti penyediaan air bersih, listrik maupun jalan sesuai dengan hasil penelitian Agenor dan Moreno (2006). Pengeluaran biaya daerah ke sektor swasta juga dapat dikurangi melalui peningkatan modal manusia dan produktivitas tenaga kerja sebagai hasil atas investasi publik (Galiani et al., 2005).

\section{Konsep Teori Investasi}

Investasi menurut Sukirno (2003) adalah pengeluaranpengeluaran untuk membeli barangbarang modal dan peralatanperalatan produksi dengan tujuan untuk mengganti dan terutama menambah barang-barang modal dalam perekonomian yang akan digunakan untuk memproduksi barang dan jasa dimasa yang akan datang. Investasi ini memiliki 3 (tiga) peran : (1) merupakan salah satu pengeluaran agregat, dimana peningkatan investasi akan meningkatkan permintaan agregat dan pendapatan nasional; (2) pertambahan barang modal sebagai akibat investasi akan menambah kapasitas produksi di masa depan dan perkembangan ini menstimulir pertambahan produksi nasional dan kesempatan kerja; dan (3) investasi selalu diikuti oleh perkembangan tekhnologi, sehingga akan memberikan kenaikan produktivitas dan pendapatan perkapita masyarakat.

Menurut Rosyidi (2000) jenis-jenis investasi dikelompokan

menjadi 4 kelompok (bertujuan agar tidak terjadi jenis investasi yang masuk dalam dua pengelompokan), antara lain:

1. Berdasarkan pada unsur pendapatan nasional:
a. Autonomos
Investment
(Investasi
Otonom),
merupakan investasi yang
perubahanya tidak
dipengaruhi oleh pendapatan,
dalam hal ini pendapatan nasional.
b. Induced Investment (Investasi terimbas) adalah investasi yang perkembangannya sangat dipengaruhi oleh tingkat pendapatan nasional.

2. Berdasarkan Subjeknya:

a.

(Investasi Pemerintah), merupakan penanaman modal yang dilakukan oleh pemerintah, baik dari pemerintah pusat maupun pemerintah daerah dengan tujuan untuk melayani kebutuhan masyarakat.

b. Private Investment (Investasi Swasta), merupakan penanaman modal yang dilakukan oleh pihak swasta dengan tujuan untuk mencari keuntungan.

3. Berdasarkan Alasannya:

\section{a. Domestic Investment}

(Investasi Dalam Negeri), merupakan penanaman modal didalam negeri, artinya penanaman modal dari negeri sendiri yang berinvestasi di dalam negeri.

b. Foreign Invesment (Investasi Asing), yaitu penanaman modal asing yang artinya investasi yang diperoleh dari luar negeri untuk digunakan didalam negeri guna mengoptimalkan sumber- 
sumber daya yang masih belum termanfaatkan.

4. Berdasarkan unsur pembentukanya:

a. Gross Investment (Investasi Bruto), merupakan total dari seluruh investasi yang dilakukan oleh suatu negara pada suatu ketika atau pada waktu tertentu.

b. Net Invesment (Investasi Neto), merupakan hasil dari investasi bruto yang dikurangi dengan penyusutan (Depreciation) atau disebut Investasi Bersih.

\section{Faktor-Faktor yang Mempengaruhi Investasi}

Menurut ahli-ahli ekonomi dalam (Sukirno, 2006) ada tiga faktor yang menentukan investasi antara lain:

1. Ramalan Mengenai Kedaan Dimasa Yang Akan Datang.

2. Tingkat Bunga.

Dalam keadaan dimana pendapatan yang akan diperolehnya dari membungakan tabungannya adalah lebih besar daripada keuntungan yang akan diperolehnya maka besar kemungkinan pengusaha tersebut akan membungakan uangnya dan membatalkannya.

3. Keuntungan yang Dicapai Perusahaan. Apabila perusahaan-perusahaan melakukan investasi dengan menggunakan tabungan yang dicapai dari bagian keuntungan yang tidak dibagikan kepada para pemegang saham, mereka tidak perlu membayar bunga keatasnya. Ini akan menurunkan biaya investasi yang dilakukan dengan memperbesar keuntungan menimbulkan suatu pengaruh lain keatas investasi.

\section{Konsep Teori Tenaga Kerja}

Kesempatan

kerja

(employment) adalah kesempatan yang tercipta akibat perkembangan ekonomi tertentu, dalam arti kesempatan kerja itu mungkin saja sudah terisi atau ada yang belum terisi. Kesempatan kerja yang selama ini dikumpulkan oleh Badan Pusat Statistik (BPS) baik melalui sensus penduduk maupun survai penduduk baik kesempatan kerja yang dirinci menurut lapangan usaha, jenis jabatan, maupun status hubungan kerja adalah menyangkut kesempatan kerja yang telah terisi. Jadi menyangkut mereka yang telah bekerja dan ini juga dapat disebut pekerja (Badan Pusat Statistik Provinsi Jambi, 2016)

Istilah employment dalam bahasa Inggris berasal dari kata kerja to employ yang berarti menggunakan dalam suatu proses atau usaha memberikan pekerjaan atau sumber penghidupan. Jadi employment berarti keadaan orang yang sedang mempunyai pekerjaan. Penggunaan istilah employment sehari-hari biasa dinyatakan dengan jumlah orang dan yang dimaksudkan ialah sejumlah orang yang ada dalam pekerjaan atau mempunyai pekerjaan. Pengertian ini mempunyai dua unsur yaitu lapangan atau kesempatan kerja dan orang yang dipekerjakan atau yang melakukan pekerjaan tersebut. Jadi pengertian employment dalam bahasa Inggris sudah jelas yaitu kesempatan kerja yang sudah diduduki (Soeroto, 2001).

Soekarni (2002) menjelaskan bahwa dalam kaitannya dengan pembangunan maka kualitas sumberdaya manusia adalah salah satu barang ekonomi yang langka 
dan oleh karenanya diperlukan pengorbanan untuk memperolehnya. Berbeda dengan komoditi ekonomi lainnya. Kualitas sumberdaya manusia tidak mempunyai wujud fisik sehingga dikategorikan sebagai benda ekonomi berbentuk jasa. Walaupun kualitas fisik dan non fisik, kesulitan akan ditemui dalam pengukurannya.

Upaya pengembangan sumberdaya manusia tujuan akhirnya adalah peningkatan kualitas manusia dan kualitas kehidupan masyarakat.

\section{Kemiskinan}

Definisi kemiskinan menurut UNDP (2009), adalah suatu situasi dimana seseorang atau rumah tangga mengalami kesulitan untuk memenuhi kebutuhan dasar, sementara lingkungan pendukungnya kurang memberikan peluang untuk meningkatkan kesejahteraan secara berkesinambungan atau untuk keluar dari kerentanan. Pada dasarnya definisi kemiskinan dapat dilihat dari dua sisi, yaitu :

1. Kemiskinan Absolut

Kemiskinan yang dikaitkan dengan perkiraan tingkat pendapatan dan kebutuhan yang hanya dibatasi pada kebutuhan pokok atau kebutuhan dasar minimum yang memungkinkan seseorang untuk hidup secara layak. Dengan demikian kemiskinan diukur dengan membandingkan tingkat pendapatan orang dengan tingkat pendapatan yang dibutuhkan untuk memperoleh kebutuhan dasarnya yakni makanan, pakaian dan perumahan agar dapat menjamin kelangsungan hidupnya. Bank dunia mendefinisikan kemiskinan absolut sebagai hidup dengan pendapatan di bawah USD \$1/hari dan kemiskinan menengah untuk pendapatan di bawah \$2/hari.

2. Kemiskinan Relatif

Kemiskinan dilihat dari aspek ketimpangan sosial, karena ada orang yang sudah dapat memenuhi kebutuhan dasar minimumnya tetapi masih jauh lebih rendah dibanding masyarakat sekitarnya (lingkungannya). Semakin besar ketimpangan antara tingkat penghidupan golongan atas dan golongan bawah maka akan semakin besar pula jumlah penduduk yang dapat dikategorikan miskin, sehingga kemiskinan relatif erat hubungannya dengan masalah distribusi pendapatan.

$$
\text { Kuncoro }
$$
mendefenisikan kemiskinan sebagai ketidakmampuan untuk memenuhi standar hidup minimum. Bank Dunia sebagaimana dikutip Prayitno (2001) menunjukkan adanya tiga dimensi kemiskinan, yaitu Pertama, kemiskinan multidimensional, artinya karena kebutuhan manusia itu bermacam-macam, maka kemiskinanpun memiliki banyak aspek. Dilihat dari kebijakan umum, maka kemiskinan meliputi aspek primer yang berupa miskin akan aset, organisasi sosial politik, dan pengetahuan serta keterampilan; dan aspek sekunder yang berupa miskin akan jaringan sosial, sumber-sumber keuangan dan informasi.

$$
\text { Todaro }
$$

mengungkapkan bahwa generalisasi yang paling tepat tentang kemiskinan adalah mereka yang ditempatkan di daerah pedesaan secara tidak seimbang, dan terutama sekali mereka yang bekerja di bidang pertanian atau kegiatan-kegiatan usaha bersama.

Aima (2003) mengungkapkan bahwa dilihat dari faktor 
penyebabnya dapat dikategorikan dalam beberapa jenis, yaitu :

1. Kemiskinan alamiah; yaitu kemiskinan timbul disuatu daerah karena sumberdaya alamnya kurang mendukung terhadap penghidupan penduduk, misalnya kering, tandus, rawan bencana alam.

2. Kemiskinan struktural, yaitu kemiskinan yang timbul disuatu wilayah karena daerahnya tidak mempunyai sarana dan prasarana untuk menunjang penghidupan masyarakat, sehingga penduduk tidak mempunyai akses untuk mendapatkan peluang ekonomi yang ada.

3. Kemiskinan kultural, yaitu kemiskinan yang timbul karena faktor sifat dan budaya manusia itu sendiri yang kurang mendukung untuk perbaikan kehidupannya seperti malas, menerima apa adanya, kurang tanggap terhadap kemajuan pembangunan.

4. Kemiskinan temporer, yaitu keadaan keluarga penduduk menjadi miskin sebagai akibat bencana alam, seperti kebakaran, kebanjiran, gempa bumi.

Menurut BPS (2006), Garis kemiskinan ditetapkan dengan terlebih dahulu menghitung batas kecukupan makanan (pangan) dan batas kecukupan non makanan.

Meskipun terdapat perbedaan dalam menentukan ukuran kemiskinan namun pada intinya tetap sama, yaitu ketidakmampuan memenuhi kebutuhan hidup minimal. Ketidakmampuan memenuhi kebutuhan hidup minimal menunjukkan rendahnya pendapatan masyarakat.

\section{Hipotesis}

Berdasarkan perumusan masalah dan tujuan penelitian maka dapat dirumuskan hipotesis sebagai berikut : diduga investasi, belanja modal, penduduk bekerja, pengangguran dan kemiskinan berpengaruh positif dan signifikan terhadap peningkatan pertumbuhan ekonomi Provinsi Jambi.

\section{METODE}

Metode penelitian yang digunakan dalam penelitian ini adalah metode analisis deskriptif kuantitatif dari data sekunder diperoleh dari instansi terkait dengan penelitian kepustakaan, ini dilakukan dengan menggunakan buku dan referensi lainnya yang sejenis atau berkaitan dengan penelitian ini yang sudah dilakukan sebelumnya. Cara ini dilakukan demi untuk memperkuat landasan teori dan mendukung studi yang bersifat komperatif analisis. Untuk menjawab permasalahan terkait faktor-faktor yang mempengaruhi pertumbuhan ekonomi Provinsi Jambi secara umum, menggunakan alat analisis regresi linear berganda semi logaritma. Data diolah dengan bantuan software SPSS seri 21.0. Model persamaan regresi dalam penelitian ini dapat diformulasikan menjadi persamaan regresi linear berganda sebagai berikut :

$Y_{t}=\alpha_{0 t}+\beta_{1} \log X_{1 t}+\beta_{2} \log X_{2 t}+$ $\beta_{3} \log X_{3 t}+\beta_{4} \log X 4_{t}+\beta_{5} \log X_{5 t}+$ $\mathrm{e}_{\mathrm{t}}$

Keterangan: $\mathrm{Y}=$ Pertumbuhan Ekonomi Provinsi Jambi (Persen); $\mathrm{X}_{1}$ $=$ Investasi $(\mathrm{PMDN}=\mathrm{PMA})$ Provinsi Jambi (Juta Rupiah); $\mathrm{X}_{2}=$ Belanja Modal Provinsi Jambi (Juta Rupiah); $\mathrm{X}_{3}=$ Penduduk Bekerja Provinsi; Jambi (Jiwa); $\mathrm{X}_{4}=$ Pengangguran (Jiwa); $\mathrm{X}_{5}=$ Kemiskinan (Jiwa); $\log =$ Logaritma; $\beta_{0}=$ Konstanta $; \beta_{1}$. ${ }_{5}=$ koefisien regresi untuk masingmasing variabel bebas; $\mathrm{e}=$ standar error; $\mathrm{t}=$ waktu 


\section{Uji Hipotesis}

Uji hipotesis secara statistik, setidaknya ini dapat diukur dari nilai statistik $t$, nilai statistik $F$ dan nilai koefisien determinasi $\mathrm{R}^{2}$ (RSquared). Perhitungan statistik disebut signifikan secara statistik apabila nilai uji statistiknya berada dalam daerah kritis (daerah dimana Ho ditolak). Sebaliknya disebut tidak signifikan bila nilai uji statistiknya berada dalam daerah dimana Ho diterima (Ghozali, 2006).

\section{Uji Parsial (Uji t-Statistik)}

Uji $\mathrm{t}$ dilakukan untuk menguji signifikansi yang ditaksir sebagai pengaruh antara variabel bebas terhadap variabel terikat, digunakan uji $\mathrm{t}$ statistik (t-test) dengan rumus sebagai berikut :

$$
t_{\text {hitung }}=\frac{a_{1}}{\operatorname{Se}\left(\alpha_{1}\right)}
$$

Dimana : $\mathrm{t}=\mathrm{t}$ - hitung; $\alpha 1=$ Koefisien regresi; $\mathrm{Se}=$ Standar Error.

Uji $\mathrm{t}$ dilakukan untuk melihat signifikansi dari pengaruh variabel bebas secara individual terhadap variabel terikat dengan menganggap variabel bebas lainnya adalah konstan. Pada tingkat signifikansi 5 persen dengan pengujian yang digunakan adalah sebagai berikut : $\mathrm{H}_{0}$ ditolak $\mathrm{H}_{1}$ diterima apabila $\mathrm{t}$ hitung $>\mathrm{t}$ tabel, yang berarti variabel independennya berpengaruh secara signifikan terhadap variabel dependen.

\section{Uji F ( Uji Simultan)}

Uji $F$ digunakan untuk menguji signifikan koefisien regresi secara bersama-sama anatara variabel dependent dengan variabel independent atau Variabel bebas secara bersama-sama terhadap variabel terikat. Nilai $F$ hitung dapat dicari dengan rumus sebagai berikut :

$$
F n=\frac{R^{2} /(K-1)}{\left(I-R^{2}\right)(n-k)}
$$

Dimana :

Fn $\quad=$ F hitung

$\mathrm{R}^{2} \quad=\quad$ Koefisien

Determinasi

$\mathrm{K}=$ Jumlah variabel bebas

$\mathrm{n}=$ Jumlah Sampel

Untuk kriteria pengujiannya yaitu sebagai berikut :

1. Apabila F hitung > F tabel, maka Ho ditolak artinya bahwa ada pengaruh yang signifikan antara variabel independen dengan variabel dependen.

2. Apabila $\mathrm{F}$ hitung < F tabel, maka Ho diterima artinya bahwa tidak adanya pengaruh yang signifikan antara variabel independent dengan variabel dependent.

\section{Operasional Variabel}

Dalam penelitian ini penulis menggunakan variabel-variabel diantaranya adalah :

1. Pertumbuhan Ekonomi (Y)

Rasio perkembangan kegiatan dalam perekonomian yang menyebabkan barang dan jasa yang diproduksi dalam masyarakat bertambah dan kemakmuran masyarakat meningkat yang di hitung selama satu tahun dengan satuan persen dikumpulkan tiap tahun selama tahun 20042015 ..

2. Investasi $\left(\mathbf{X}_{\mathbf{1}}\right)$

Total pengeluaran atau perbelanjaan penanampenanam modal atau perusahaan untuk membeli barang-barang modal dan perlengkapan-perlengkapan produksi untuk menambah kemampuan memproduksi barang dan jasa yang tersedia dalam perekonomian yang bersumber dari dalam negeri ataupun luar negeri, sehingga 
investasi disebut juga dengan penanaman modal yang diukur dalam rupiah pertahun dikumpulkan tiap tahun selama tahun 2004-2015..

3. Belanja Modal ( $\left.\mathbf{X}_{2}\right)$

Jumlah anggaran dalam APBD yang penggunaannnya untuk pengeluaran dalam rangka pembelian/ pengadaan atau pembangunan aset tetap berwujud yang mempunyai nilai manfaat lebih dari 12 (duabelas) bulan untuk digunakan dalam kegiatan pemerintahan, seperti dalam bentuk tanah, peralatan dan mesin, gedung dan bangunan, jalan, irigasi dan jaringan dan aset tetap lainnya, yang diukur dalam satuan rupiah dikumpulkan tiap tahun selama tahun 2004-2015.

4. Penduduk Bekerja ( $\left.\mathbf{X}_{\mathbf{3}}\right)$

Jumlah masyarakat yang bekerja pada sektor ekonomi untuk semua jenis lapang usaha yang terdapat di Provinsi Jambi dalam satuan rupiah dan dikumpulkan tiap tahun 20042015.

5. Pengangguran $\left(\mathbf{X}_{4}\right)$

Jumlah masyarakat yang menganggur atau tidak bekerja pada sektor ekonomi untuk semua jenis lapang usaha yang terdapat di Provinsi Jambi dalam satuan rupiah dan dikumpulkan tiap tahun selama tahun 2004-2015.

6. Kemiskinan $\left(\mathbf{X}_{\mathbf{5}}\right)$

Kondisi penduduk dimana tidak terpenuhinya kebutuhan pokok atau kebutuhan dasar (makanan, pakaian, rumah atau tempat berlindung, pendidikan, dan kesehatan) sehingga standar hidup layak tidak tercapai. Pengukuran variable kemiskinan dalam penelitian ini menggunakan jumlah penduduk miskin di Provinsi Jambi dengan satuan jiwa dikumpulkan tiap tahun selama tahun 2004-2015.

HASIL

Estimasi Pengujian Model Kuantitatif

Faktor-Faktor Yang Mempengaruhi Pertumbuhan Ekonomi Dengan Regresi Linear Berganda

Analisa perumusan masalah yang kedua digunakan dalam pengujian model kuantitatif dalam penelitian ini adalah dengan menggunakan Metode Linier Berganda, dengan menggunakan teknik Ordinary Least Square dengan menggunakan program SPSS versi 21.0, dimana hasil Hipotesis pengujian model Linier Berganda dapat dilihat sebagai berikut :

Tabel 1

Coefficients $^{\mathrm{a}}$

\begin{tabular}{|c|c|c|c|c|c|c|}
\hline \multirow{2}{*}{\multicolumn{2}{|c|}{ Model }} & \multicolumn{2}{|c|}{$\begin{array}{l}\text { Unstandardized } \\
\text { Coefficients }\end{array}$} & \multirow{2}{*}{$\begin{array}{c}\text { Standardized } \\
\text { Coefficients } \\
\text { Beta }\end{array}$} & \multirow[t]{2}{*}{$\mathrm{t}$} & \multirow[t]{2}{*}{ Sig. } \\
\hline & & B & $\begin{array}{l}\text { Std. } \\
\text { Error }\end{array}$ & & & \\
\hline \multirow{6}{*}{1} & (Constant) & 2,873 & 2,698 & & 1,065 & ,328 \\
\hline & $\log X 1$ &, 171 & ,082 & ,449 & 2,089 & ,082 \\
\hline & $\log X 2$ & ,090 & ,076 & , 127 & 1,191 & ,278 \\
\hline & $\log X 3$ & ,899 & ,345 & ,406 & 2,603 &, 040 \\
\hline & $\log X 4$ &, 008 &, 054 & ,009 & , 158 & ,880 \\
\hline & $\log X 5$ &,- 542 & ,204 &,- 208 & $-2,657$ & ,038 \\
\hline
\end{tabular}


Keterangan:*) Signifikan pada $\alpha=5 \%$

\section{$Y_{t}=2,873+0,171 \log X_{1 t}+0,090 \log X_{2 t}+0,899 \log X_{3 t}+0,08 \log X_{4 t}-$ $0,542 \log X_{5 t}+e_{t}$}

Hasil persamaan regresi diatas secara keseluruhan bahwa nilai koefisien $\beta_{0}$ sebesar 2,873 artinya, apabila selama tahun 2004 sampai 2015 tidak terjadi perubahan variabel investasi $\left(\mathrm{X}_{1 \mathrm{t}}\right)$, belanja modal $\left(\mathrm{X}_{2 \mathrm{t}}\right)$, Penduduk Bekerja $\left(\mathrm{X}_{3 \mathrm{t}}\right)$, pengangguran $\left(\mathrm{X}_{4 \mathrm{t}}\right)$ dan kemiskinan $\left(\mathrm{X}_{5 \mathrm{t}}\right)$ tidak mengalami perubahan atau dengan asumsi konstan, maka pertumbuhan ekonomi $\left(\mathrm{Y}_{\mathrm{t}}\right)$ untuk Provinsi Jambi akan mengalami peningkatan sebesar 2,873 persen. Meningkatnya pertumbuhan ekonomi bisa terjadi, diakibatkan faktor yang mempengaruhi pertumbuhan ekonomi tidak hanya variabel dalam penelitian ini. Meningkatkan pertumbuhan ekonomi sudah dilakukan oleh pemerintah dalam berbagai upaya namun tetap saja ketidakmampuan mengakses sumbersumber permodalan, juga karena infrastruktur yang juga belum mendukung untuk dimanfaatkan masyarakat memperbaiki kehidupannya, selain itu juga karena SDM, SDA, sistem, dan juga tidak terlepas dari sosok pemimpin agar kesejahteraan masyarakat terwujud.

Sedangkan koefisien regresi variabel $X_{1 t}\left(\beta_{1}\right)$ diperoleh nilai sebesar 0,171 , artinya apabila terjadi kenaikan atau peningkatan investasi $\left(\mathrm{X}_{1 \mathrm{t}}\right)$ sebesar 1 persen, maka akan meningkatkan pertumbuhan ekonommi $\left(\mathrm{Y}_{\mathrm{t}}\right)$ untuk Provinsi Jambi sebesar 0,171 persen dengan asumsi bahwa variabel lain tetap (Cateris paribus) atau tidak terjadi perubahan atau konstan. Hasil regresi untuk koefisien investasi tersebut, menggambarkan bahwa kondisi dan pengaruh investasi terhadap peningkatan pertumbuhan ekonomi
Provinsi Jambi masih rendah, jauh dari harapan. Pertumbuhan ekonomi yang menjadi tolak ukur pembangunan ekonomi, belum optimal ditingkatkan dengan adanya investasi yang menjadi permasalahan makro akan berdampak melambatnya pembangunan ekonomi serta berkurangnya kesejahteraan masyarakat. Kondisi demikian perlu menjadi perhatian pemerintah daerah kedepannya untuk segera mengambil kebijakan yang tepat dan efektif agar investasi berpengaruh besar terhadap peningkatan pertumbuhan ekonomi Provinsi Jambi.

Koefisien regresi variabel $\mathrm{X}_{2 \mathrm{t}}$ $\left(\beta_{2}\right)$ diperoleh nilai sebesar 0,090, artinya apabila terjadi kenaikan atau peningkatan belanja modal $\left(\mathrm{X}_{2 \mathrm{t}}\right)$ sebesar 1 persen, maka akan meningkatkan pertumbuhan ekonomi Provinsi Jambi $\left(\mathrm{Y}_{\mathrm{t}}\right)$ sebesar 0,090 persen dengan asumsi bahwa variabel lain tetap (Cateris paribus) atau tidak terjadi perubahan atau konstan. Berdasarkan hasil estimasi untuk variabel belanja modal $\mathrm{X}_{2 \mathrm{t}}$ $\left(\beta_{2}\right)$, semestinya dapat meningkatkan pertumbuhan ekonomi lebih besar lagi. Namun ini disebabkan kondisi daerah yang memungkinkan peran belanja modal tidak efektif dalam meningkatkan pertumbuhan ekonomi.

Untuk koefisien regresi variabel $X_{3 t}\left(\beta_{3}\right)$ diperoleh nilai sebesar 0,899 , artinya apabila terjadi kenaikan atau peningkatan penduduk bekerja $\left(\mathrm{X}_{3 \mathrm{t}}\right)$ sebesar 1 persen, maka akan meningkatkan pertumbuhan ekonomi Provinsi Jambi $\left(\mathrm{Y}_{\mathrm{t}}\right)$ sebesar 0,899 persen dengan asumsi bahwa variabel lain tetap (Cateris paribus) atau tidak terjadi perubahan atau 
konstan. Hasil estimasi ini menunjukkan bahwa penduduk bekerja sangat diperlukan untuk meningkatkan pertumbuhan ekonomi Provinsi Jambi. Penduduk bekerja yang besar, sering juga diikuti oleh banyaknya lapangan kerja baru yang terserap. Sehingga dapat meningkatkan kesejahteraan masyarakat dan akan berdampak meningkatkan pertumbuhan ekonomi Provinsi Jambi.

Untuk koefisien regresi variabel $X_{4 t}\left(\beta_{4}\right)$ diperoleh nilai sebesar 0,008 , artinya apabila terjadi kenaikan atau peningkatan pengangguran $\left(\mathrm{X}_{4 \mathrm{t}}\right)$ sebesar 1 persen, maka akan meningkatkan pertumbuhan ekonomi Provinsi Jambi $\left(Y_{t}\right)$ sebesar 0,008 persen dengan asumsi bahwa variabel lain tetap (Cateris paribus) atau tidak terjadi perubahan atau konstan. Hasil estimasi ini menunjukkan bahwa pengangguran dapat mempengaruhi tinggi rendahnya pertumbuhan ekonomi Provinsi Jambi. Dalam hal ini pengangguran di Provinsi Jambi semestinya cenderung dapat menurunkan pertumbuhan ekonomi, namun sebaliknya meningkatkan pertumbuhan ekonomi. Hal ini dikarenakan banyaknya pengangguran usia produktif dapat meningkatnya penyerapan tenaga kerja murah. Provinsi Jambi yang masih tahap perkembangan pembangunan, tentu perlu upaya memenuhi sumber daya manusia yang berkualitas sebagai modal pembangunan. Dengan adanya pengangguran diharapkan dapat menambah dan membuka peluang lapangan kerja baru dengan meningkatnya taraf hidup masyarakat. Hanya saja penyerapan tenaga kerja banyak di sektor informal. Di samping itu pula diharapkan akan meningkatkan tingkat pendidikan yang akan merubah pola pikir dalam bidang kependudukan untuk lebih banyak bekerja disektor formal, sehingga angka pengangguran dapat diminimalkan.

Begitu juga dengan koefisien regresi variabel $\mathrm{X}_{5 \mathrm{t}}\left(\beta_{5}\right)$ diperoleh nilai sebesar $-0,542$, artinya apabila terjadi kenaikan atau peningkatan angka kemiskinan $\left(\mathrm{X}_{5 \mathrm{t}}\right)$ sebesar 1 persen, maka akan menurunkan pertumbuhan ekonomi Provinsi Jambi $\left(\mathrm{Y}_{\mathrm{t}}\right)$ sebesar 0,542 persen dengan asumsi bahwa variabel lain tetap (Cateris paribus) atau tidak terjadi perubahan atau konstan. Hasil estimasi ini menunjukkan bahwa kemiskinan menjadi penghambat pembangunan ekonomi Provinsi Jambi. Meskipun kemiskinan mengalami penurunan akan tetapi belum mampu meningkatkan pertumbuhan ekonomi daya saing yang tinggi. Disamping itu juga etos kerja SDM Provinsi Jambi rendah. Memungkinkan menyebabkan orang miskin menggunakan tenaga mereka untuk berpartisipasi dalam pertumbuhan ekonomi, tetapi kemiskinan akibat kurangnya pendidikan, serta gizi dan kesehatan yang buruk mengurangi kapasitas mereka untuk bekerja.

Dari kelima variabel yang mempengaruhi kemiskinan Provinsi Jambi. Hanya variabel penduduk bekerja $\left(\mathrm{X}_{3 \mathrm{t}}\right)$ dan kemiskinan $\left(\mathrm{X}_{5} \mathrm{t}\right)$ yang relatif besar pengaruhnya dan signifikan terhadap pertumbuhan ekonomi dan sisanya tidak berpengaruh signifikan. Namun yang terjadi di Provinsi Jambi, peningkatan pengangguran justru menambah pertumbuhan ekonomi. Namun tidak berpengaruh signifikan dalam meningkatkan pertumbuhan ekonomi.

\section{Uji Hipotesis}

1. Uji Parsial (Uji-t) 
Berdasarkan uji statistik parsial dengan tingkat keyakinan $\alpha=$ $5 \%$, diperoleh nilai t-statistik untuk variabel $X_{1 \mathrm{t}}\left(\beta_{1}\right)$ yang nilainya lebih besar dari t-prob $(2,089>0,082)$, artinya $\mathrm{H}_{0}$ ditolak $\mathrm{H}_{1}$ diterima. Hal ini menunjukkan bahwa investasi $\left(\mathrm{X}_{1 \mathrm{t}}\right)$ selama periode 2004 sampai dengan 2015 berpengaruh signifikan terhadap peningkatan pertumbuhan ekonomi $\left(\mathrm{Y}_{\mathrm{t}}\right)$ di Provinsi Jambi pada tingkat keyakinan $\alpha$ diatas 5 persen. Namun dalam penelitian ini menggunakan tingkat keyakinan $\alpha 5$ persen. Ini berarti investasi belum berpengaruh signifikan dan kurang efektif dalam meningkatkan pertumbuhan ekonomi Provinsi Jambi.

Begitu juga dengan nilai $t-$ statistik untuk variabel $\mathrm{X}_{2 \mathrm{t}} \quad\left(\beta_{2}\right)$ diperoleh nilai yang lebih besar dari t-prob $(1,191>0,278)$, artinya $\mathrm{H}_{0}$ ditolak $\mathrm{H}_{1}$ diterima. Ini menunjukan bahwa belanja modal $\left(\mathrm{X}_{2 \mathrm{t}}\right)$ berpengaruh signifikan terhadap pertumbuhan ekonomi $\left(\mathrm{Y}_{\mathrm{t}}\right)$ di Provinsi Jambi pada tingkat keyakinan $\alpha$ diatas 5 persen. Namun dalam penelitian ini menggunakan tingkat keyakinan a 5 persen. Ini berarti belanja modal belum berpengaruh signifikan dan kurang efektif dalam meningkatkan pertumbuhan ekonomi Provinsi Jambi. Maka dari itu perlu kebijakan yang tepat dalam mengatasi persoalan ini agar belanja modal berpengaruh signifikan terhadap pertumbuhan ekonomi Provinsi Jambi.

Sedangkan nilai t-statistik untuk variabel $\mathrm{X}_{3 \mathrm{t}}\left(\beta_{3}\right)$ diperoleh nilai yang lebih besar dari t-prob $(2,603>0,040)$, artinya $\mathrm{H}_{0}$ ditolak $\mathrm{H}_{1}$ diterima. Artinya bahwa penduduk bekerja $\left(\mathrm{X}_{3 \mathrm{t}}\right)$ berpengaruh signifikan terhadap pertumbuhan ekonomi $\left(\mathrm{Y}_{\mathrm{t}}\right)$ di Provinsi Jambi pada tingkat keyakinan $\alpha$ dibawah 5 persen. Namun demikian penduduk bekerja sangat efektif dalam meningkatkan pertumbuhan ekonomi Provinsi Jambi dibandingkan variabel lainnya. Hanya saja pengaruhnya tidak terlalu besar.

Untuk nilai t-statistik untuk variabel $\mathrm{X}_{4 \mathrm{t}}\left(\beta_{4}\right)$ diperoleh nilai yang lebih rendah dari $\mathrm{t}$-prob $(0,158<0,880)$, artinya $\mathrm{H}_{0}$ diterima $\mathrm{H}_{1}$ ditolak. Artinya bahwa pengangguran $\left(\mathrm{X}_{4 \mathrm{t}}\right)$ tidak berpengaruh signifikan terhadap peningkatan pertumbuhan ekonomi $\left(\mathrm{Y}_{\mathrm{t}}\right)$ di Provinsi Jambi pada tingkat keyakinan $\alpha$ diatas 5 persen. Pengangguran di Provinsi Jambi cenderung dapat menurunkan pertumbuhan ekonomi namun hasil estimasi meningkatkan pertumbuhan ekonomi. Hal ini dikarenakan banyak usia produktif yang menganggur serta meningkatnya penyerapan tenaga kerja yang tidak berkelanjutan. Sehingga jauh dari tingkat kesejahteraan hanya dapat memenuhi kebutuhan dasar bersifat sementara. Untuk itu perlu upaya memenuhi sumber daya manusia yang berkualitas sebagai modal pembangunan dalam meningkatkan kesejahteraan masyarakat. Agar pengangguran berpengaruh negatif signifikan terhadap penurunan pertumbuhan ekonomi.

Nilai t-statistik untuk variabel $\mathrm{X}_{5 \mathrm{t}}\left(\beta_{5}\right)$ yang nilainya lebih besar dari t-prob $(2,657>0,038)$, artinya $\mathrm{H}_{0}$ ditolak $\mathrm{H}_{1}$ diterima. Hal ini menunjukkan bahwa kemiskinan $\left(\mathrm{X}_{5 \mathrm{t}}\right)$ selama periode 2004 sampai dengan 2015 berpengaruh signifikan terhadap penurunan pertumbuhan ekonomi $\left(\mathrm{Y}_{\mathrm{t}}\right)$ di Provinsi Jambi pada tingkat keyakinan $\alpha$ diatas 5 persen. 
Tabel 2

ANOVA $^{\mathrm{a}}$

\begin{tabular}{|c|c|c|c|c|c|c|}
\hline \multicolumn{1}{|c|}{ Model } & Sum of Squares & Df & Mean Square & F & Sig. \\
\hline \multirow{4}{*}{1} & Regression &, 117 & 5 &, 023 & 106,980 &, $000^{\mathrm{b}}$ \\
& Residual &, 001 & 6 &, 000 & & \\
& Total &, 118 & 11 & & & \\
\hline
\end{tabular}

Berdasarkan persamaan diatas, diperoleh nilai F-statistiknya lebih besar dari nilai F-prob $(106,980>0,000)$ pada tingkat keyakinan $\alpha=5 \%$. Artinya, $\mathrm{H}_{0}$ ditolak dan $\mathrm{H}_{1}$ diterima. Ini menunjukan bahwa secara bersamasama variabel investasi $\left(\mathrm{X}_{1 \mathrm{t}}\right)$, belanja modal $\left(\mathrm{X}_{2 \mathrm{t}}\right)$, penduduk bekerja $\left(\mathrm{X}_{3 \mathrm{t}}\right)$, pengangguran $\left(\mathrm{X}_{4 \mathrm{t}}\right)$ dan kemiskinan $\left(\mathrm{X}_{5 \mathrm{t}}\right)$ berpengaruh signifikan terhadap naik turunnya pertumbuhan ekonomi $\left(\mathrm{Y}_{\mathrm{t}}\right)$ di Provinsi Jambi selama periode 2004 sampai dengan 2015.

Tabel 3

Model Summary ${ }^{b}$

\begin{tabular}{|l|r|r|r|r|}
\hline Model & \multicolumn{1}{|c|}{ R } & R Square & Adjusted R Square & Std. Error of the Estimate \\
\hline 1 &, $994^{\mathrm{a}}$ &, 989 &, 980 &, 01480 \\
\hline
\end{tabular}

Hasil perhitungan R- squared yang ditunjukkan pada persamaan diatas diperoleh nilai $\mathrm{R}^{2}$ sebesar 0,989 . Hal ini menunjukan bahwa sekitar 98,90 persen naik turunnya pertumbuhan ekonomi $\left(\mathrm{Y}_{\mathrm{t}}\right) \mathrm{di}$ Provinsi Jambi dipengaruhi oleh variabel investasi $\left(\mathrm{X}_{1 \mathrm{t}}\right)$, belanja modal $\left(X_{2 t}\right)$, penduduk bekerja $\left(X_{3 t}\right)$, pengangguran $\left(\mathrm{X}_{4 \mathrm{t}}\right)$ dan kemiskinan $\left(\mathrm{X}_{5 \mathrm{t}}\right)$. Sedangkan sisanya 1,10 persen, dijelaskan oleh variabel lain yang tidak dimasukan kedalam persamaan regresi.

\section{SIMPULAN}

Berdasarkan hasil penelitian
dan pembahasan maka dapat
disimpulkan beberapa hal sebagai
berikut :
"Penduduk Bekerja dan kemiskinan
mempengaruhi perubahan naik
turunnya pertumbuhan ekonomi
Provinsi Jambi secara signifikan baik
secara individu maupun simultan
yaitu sebesar 98,90 persen dengan
tingkat keyakinan $\alpha=5$ persen

\section{DAFTAR PUSTAKA}

Arsyad, Lincolin,2009,Ekonomi Pembangunan, Edisi Ketiga, FEUGM,Penerbit STIE YKPN, Yogyakarta.

Aima, Havidz,2003. An evaluation of poverty alleviation in sarko distrik, central Luzon states university

Badan Pusat Statistik, Provinsi Jambi Dalam Angka 2015 : BPS.

Bappenas, BPS, UNDP (2009), "Laporan Pembangunan Manusia Indonesia 2009, Menuju Konsensus Baru Demokrasi dan pembangunan Manusia Di Indonesia", Bappenas, BPS, UNDP. Jakarta

Bappenas,2004, Rencana Strategik Penanggulan Kemiskinan di Indonesia,Jakarta

Boediono,2008. Teori Pertumbuhan Ekonomi, BPFE UGM Yogyakarta.

Djoyohadikusumo, Sumitro,2006. Perkembangan Pemikiran Ekonomi (Dasar Teori 
Ekonomi Pertumbuhan dan

Pembangunan) LP3S, Jakarta.

Halim, Abdul. 2009. Akuntansi

Sektor Publik : Akuntansi

Keuangan Daerah. Edisi 3.

Salemba 4 : Jakarta.

Hakim, Abdul,2002. Ekonomi pembangunan, PT Ekonesia, Jakarta.

Hariyati, Wuri, 2006. Pengaruh Pengeleuaran Pemerintah

Provinsi Terhadap

Pertumbuhan Ekonomi

Regional Indonesia Selama

Tahun 1993-2005, Tesis

Program Studi Ilmu Ekonomi

Program Pascasarjana

Ekonomi Universitas

Indonesia.

Jhingan, M.L,2006. Ekonomi

Pembangunan dan

Perencanaan, PT. Raja

Grafindo Persada, Jakarta.

Kuncoro Mudrajat,2006. Ekonomika Pembangunan

(Teori,

Masalah dan Kebijakan),

Edisi ketiga.UPP-AMP

YKPN. Yogyakarta.

Mangkoesobroto G.2008. Ekonomi

Publik. BPFE, Yogyakarta.

Musliadi. (2013). Analisis Pengaruh

Dana Otonomi Khusus,

Pendapatan Asli Daerah Dan

Belanja Modal Terhadap

Kemiskinan Pada

Kabupaten/ Kota Di

Provinsi Aceh Tahun 2008-

2012. Yogyakarta: Tesis

Universitas Gajah Mada.

Prayitno,2001. Pendidikan Karakter

Dalam Pembangunan Bangsa.

PT. Grafindo Persada.

Jakarta.

Reksohadiprojo, Prayitno, 2009,

Ekonomi Makro, Analisa

Pendapatan Nasional, BP FE-

UGM, Yogyakarta.

Sadikin, 2013. pengaruh pertumbuhan ekonomi dan ketimpangan pendapatan terhadap kemiskinan di
Provinsi Jambi pada 20052010.

Sidik, Machfud. 2002. Optimalisasi Pajak Daerah dan Retribusi Daerah dalam Rangka Meningkatkan Kemampuan Keuangan Daerah. Makalah disampaikan Acara Orasi Ilmiah. Bandung. 10 April 2002.

Siregar, H dan D. Wahyuniarti. 2007. Dampak Pertumbuhan Ekonomi terhadap Penurunan Jumlah Penduduk Miskin. MB-IPB. Bogor.

Sirlinawati,2012. Analisis

Determinan Pendapatan

Penduduk Miskin Dan

Hubungannya dengan

Program Pengentasan

Kemiskinan Di Dusun Muara

Buat Kecamatan Batin III Ulu

Kabupaten Bungo.

Simanjuntak, Robert. 2001.

Kebijakan Pungutan

Daerah di Era Otonomi,

Domestic Trade,

Decentralization and

Globalization: A One Day

Conference. LPEM-UI.

Jakarta.

Sukirno, Sadono. 2000, "Ekonomi Pembangunan”. Proses, Masalah, Dasa Kebijakan. Kencana Prenada Media Group, Jakarta.

Sukirno, Sadono. 2004. Makro Ekonomi Teori Pengantar. Jakarta: PT Raja Grafindo Perkasa.

Sukirno, Sadono, 2008. Ekonomika Pembangunan, LP-FE, Universitas Indonesia, Jakarta.

Statistik Keuangan Daerah berbagai Edisi. Biro Keuangan Daerah, Provinsi Jambi.

Straub, $\quad$ Stéphane. 2008. Infrastructure and Growth in Developing Countries: 


$\begin{array}{lr}\text { Recent } & \text { Advances and } \\ \text { Research } & \text { Challenges. } \\ \text { Working } & \text { Paper. } \\ \text { Development } & \text { Research } \\ \text { Department. } & \text { Research } \\ \text { Support Team. World Bank. }\end{array}$

Tambunan, Tulus, 2003. Kesempatan

Kerja, Produktivitas dan

Sumberdaya

manusia",Media Ekonomi, Vol.IV No.1, 321-339.

Tan Syamsurijal, 2010. Perencanaan

Pembangunan (Teori dan

implementasi pada

Pembangunan Daerah),

Jambi Fakultas Ekonomi universtias Jambi.

Todaro,MP. 2003. Ekonomi di Dunia Ketiga, Ghalia Indonesia, Jakarta
Todaro P. Michael,2006, Pembangunan Ekonomi di Dunia Ketiga. Erlangga. Jakarta
Usman, Sunyoto, 2004.
Pembangunan Dan
Pemberdayaan Masyarakat. Yogyakarta : Pustaka Pelajar Offset.

Wijaya, 2009. Kompedium Ekonomika. BPFE. Yogyakarta.

Peraturan Pemerintah No. 105 tahun 2000. Tentang Pengolaan Dan Pertanggungjawaban Keuangan Daerah.

Peraturan Menteri Dalam Negeri No. 13 tahun 2006. Tentang Pedoman Pengelolaan Keuangan Daerah.

Undang-Undang No. 17 tahun 2003. Tentang Keuangan Negara.

Undang-undang Republik Indonesia No. 32 tahun $2004 \quad$ Tentang

Pemerintahan Daerah.
Undang-undang Nomor

33 Tahun 2004 tentang Perimbangan. ,2006, Indikator Ekonomi Provinsi Jambi 2006, Kerjasama BAPPEDA dan BPS Provinsi Jambi. 